\title{
Water Supply Challenges and Storm Water Management in Kisii Municipality, Nyakomisaro Sub Catchment, Kenya
}

\author{
Christopher Misati Ondieki, Bisley Mokaya Kebaso \\ Kenyatta University, Nairobi City, Kenya \\ Email: chrismisati@hotmail.com, kebasob@gmail.com
}

How to cite this paper: Ondieki, C.M. and Kebaso, B.M. (2017) Water Supply Challenges and Storm Water Management in Kisii Municipality, Nyakomisaro Sub Catchment, Kenya. Open Access Library Journal, 4: e3769.

https://doi.org/10.4236/oalib.1103769

Received: June 27, 2017

Accepted: September 16, 2017

Published: September 19, 2017

Copyright ( 2017 by authors and Open Access Library Inc.

This work is licensed under the Creative Commons Attribution International License (CC BY 4.0).

http://creativecommons.org/licenses/by/4.0/

\begin{abstract}
The water supply system in Kisii municipality faces many challenges. The municipality is located within the Nyakomisaro sub catchment and the water supply relies heavily on the River Nyakomisaro. The water supply system is dilapidated and there is a lot of wastage due to poor maintenance. The state of the catchment does not permit all year round supply due to degradation and climatic variability and this compromises sub-catchment integrity, given the ever rising population and increasing human activities. This study investigated challenges for water supply and stream flow management using stream flow and rainfall data from the hydrometric network and structured questionnaires for water supply and storm water management in the sub catchment. Analysis was done using standard statistical methods. When dry spells last for a week, severe water shortage causes people to travel long distances in search of it and is generally expensive thereby limiting domestic and commercial activities. Dumping of solid waste along the river, road and house construction sites affect river flow. Fish farming and eucalyptus trees along the river diminish the flow. There are no proper drainage systems in the Nyakomisaro sub catchment. Reliance on river water could be reduced by rainwater harvesting yet also flooding and poor sanitation affect water supply and ecosystem management. To improve on the water supply and drainage systems, planning for water management in the sub catchment should incorporate all stakeholders including: NEMA, GWASCO and WRMA and the community.
\end{abstract}

\section{Subject Areas}

Atmospheric Sciences, Environmental Sciences

\section{Keywords}

Nyakomisaro, Water Supply, Kisii Municipality, WRMA, GWASCO 


\section{Introduction}

Water use conflicts in Nyakomisaro arise from shortages in different demands in urban areas often in competition with the rural demands [1]. The conflicts are on the rise in both areas due to increased water demands by the increasing population and urbanization [2] [3]. A strategy for water accessibility to all is crucial to health and development. This requires data [4] [5] for use in planning and management in domestic water use [6] with accurate projections. Water demand for different sectors is based on level of economic development, food consumption patterns, cropping patterns and climatic factors (www.iwmi.cgiar.org).

Reference [7] and the International Water Management Institute (IWMI) point out that water demand projections (WDPs) are widely used for future water resource planning as water projects take time to complete. Understanding the balance of all water supplies and demands in any region is a necessary first step toward effective water resource planning and management. The IWMI shows that accurate WDPs can optimize water development efforts and better planning can alleviate water-related conflicts, reduce environmental degradation, target investments in water infrastructure and help design better adaptation measures.

Kisii municipality experiences risk of significant episodic water scarcity and storm water hazards due to hydrologic variability. This has ramifications on the economy, poverty, and ecosystem viability. River Nyakomisaro flows vary as a result of rainfall changes and variations in water supplies [8] [9] which invariably threaten future food and water supplies in the municipality. Increased pressure on freshwater resources in Kisii especially from increased population demand more water thereby reducing river flow. The challenges of ensuring good water quantity and quality are becoming increasingly prominent as population increases. The available surface and underground water supplies are being contaminated, and less fresh water is available such that the concern of quality and quantity is imminent [10] [11] [12]. This study is relevant for water supply design purposes and the construction of sewer systems in Kisii municipality.

The main river passes through the town where many activities take place with rapid expansion that was clearly evident after the 2007/2008 post-election violence and this has exerted a lot of pressure on available water resources. Over the past three decades, the Nyakomisaro sub catchment has faced challenges of anthropogenic nature which have resulted in the gradual drying up of the headwaters and consequent destruction of previously existing wetlands in the sub catchment [12] [13]. The water of river Nyakomisaro has deteriorated in quantity and quality leading to water shortages. Out of the 4700 water pipe connections in Nyakomisaro sub catchment about 2700 are abandoned, the main reason being; inadequate water [14] [15]. This research on the sub-catchment of Nyakomisaro passing through Kisii municipality in relation to water supply unlike other studies [16] [17] seeks to examine the potential of the water supply system in Kisii municipality to sustain the impeding population pressure. 
The diverse availability of water resources information is captured in a range of types of data including the statistics of meteorological and hydrological elements. These elements include: precipitation, river levels and flow rates, groundwater levels, evapotranspiration and storm water pollution [18]. An attempt was made to establish the factors affecting storm water management and the strategies to mitigate the challenges identified at Nyakomisaro sub catchment. Reference [19] confirms that storm water management strategy can mitigate the impacts of increased streamflow and storm water pollution through site design strategies and distributed structural best management practices.

Extreme rainfall events have a large effect on society and can lead to loss life and property, for instance, by causing landslides and flooding [9] [20]. This is preventable by proper design of hydraulic structures, yet there are also challenges of ensuring good water quality and quantity for the increasing population and land use changes [21] [22]. In Kisii municipality, most of the surface and underground water supplies have been contaminated hence less fresh water is now available due to poor storm water management [10]. Stormwater from urban areas typically contains large amounts of litter and other gross pollutants, sediments, fecal bacteria, hydrocarbons, nutrients, heavy metals and other pollutants. Furthermore, because urban catchments typically contain large areas of roads, carparks and other impervious surfaces, large volumes of runoff can be generated in a short period of time, resulting in downstream flooding and erosion. If unmanaged, stormwater can result in severe impacts on downstream waterways (www.environment.tas.gov.au). Research ought to be done to address the menaces brought by storm water.

River Nyakomisaro, a tributary of River Gucha starts from interlocking hills of Nyanguru and Bobaracho has its flows monitored at RGS-1KA5 (Figure 1). There is one Meteorological Station in Kisii (63709) on Latitude of $0^{\circ} 04^{\prime}$ South, Longitude of $34^{\circ} 48^{\prime}$ East and altitude of $1493 \mathrm{~m}$ above sea level. Nyakomisaro River serves Kisii municipality which covers an area of $29 \mathrm{~km}^{2}$ out of which 8 $\mathrm{km}^{2}$ is within the Central Business District [14] [23].

The area has a modified highland climate with average annual rainfall approximated at $1500 \mathrm{~mm}$ and the temperature ranges from $10^{\circ} \mathrm{C}$ to $31^{\circ} \mathrm{C}$. The long rainy season occurs between March and May and the short rainy season occurs between October and December [24]. The study area is within Kisii Highlands which experiences relief type of rainfall. Since the rains are torrential, the town is severely affected as it lacks an efficient drainage system. Water for use is obtained from rivers and from water harvesting (www.kisii.com; [14]).

The sub catchment has a relatively high population density currently standing at $2862 / \mathrm{km}^{2}$ due to sub divisions with individual family plots averaging 1.5 acres. In the sub catchment, the water and land has become target of pollution by the chemicals farmers use, from coffee farms and tea farms as well as the bottling done by Coca-Cola Company. As the municipality expands, more problems are projected into the future. 


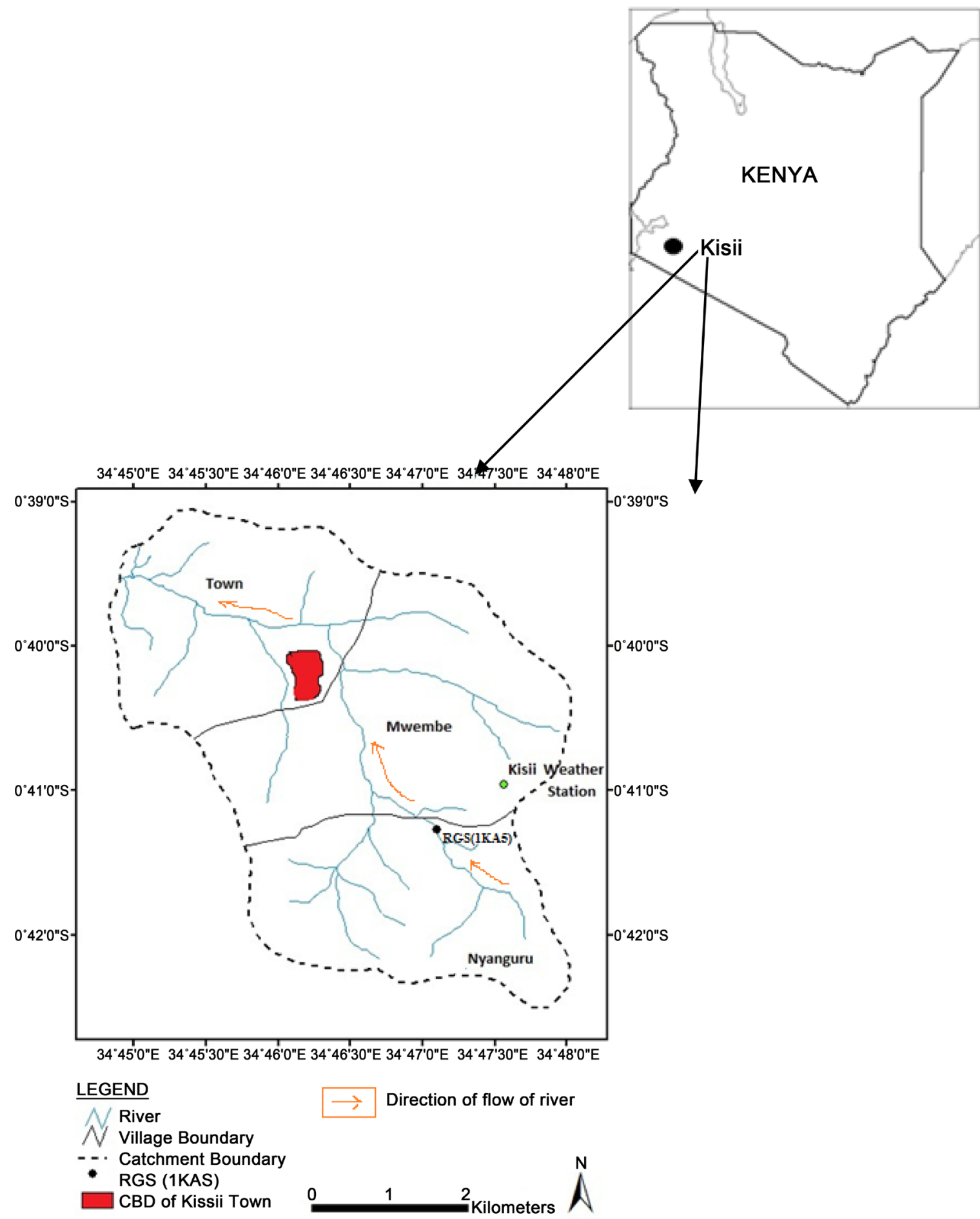

Figure 1. Nyakomisaro Sub catchment [15].

\section{Methods}

Water supply data was obtained from Gusii Water Supply Company (GWASCO) for the period between 1995 and 2015. A sample of 408 households was selected such that in each village, the first nearest house was selected, followed by the systematic random sampling of houses along the survey direction [25]. Studies 
on water supply and storm water management were conducted in three sections; villages on upstream near Nyanguru, villages on midstream near a coffee factory and Mwembe, and; Kisii town section on the lower stream.

The water supply data was based on questionnaires and interview schedules targeting GWASCO, District Water Office, Provincial Health Office, Water Resource Management Authority (WRMA) and water consumers. The information collected sought the extent of water use in the municipality and the effect of the Nyakomisaro hydrological characteristics on water supply and related problems. The storm water management data collection targeted NEMA in addition to the above respondents. The water supply data was analyzed quantitatively while the storm water management data was subjected to qualitative analysis.

\section{Results}

\subsection{Water Supply in Nyakomisaro Sub Catchment}

The study indicated that just after one week of dry spells, many people suffer from water supply problems and this may be attributed to the relationship between stream flow and water supply [26]. The municipal water supply is unable to meet the water supply demand thereby limiting water supply to core urban areas with low income areas having to rely on water vendors and wells. Only $7 \%$ of households have piped water, $66.6 \%$ depend on river water and $20 \%$ on springs for daily life and remaining percentages of the population use pond, dam, lake, well, and tanks. The majority of the population put pressure on the available water on the main river passing through Kisii municipality. Water allocation in the Nyakomisaro sub catchment is done by WRMA which carries out discharge measurements to determine the amount of river flow. GWASCO applies for water permit for supplying water to its clients based on hydrological assessment of WRMA yet the number of households depending on piped water is alarmingly low.

Relatively small changes in rainfall affect water availability in the sub catchment. This implies that during low rains, the value of this precious commodity increases immensely. This water scarcity will get worse over time in Kisii Municipality given that population increases drastically as shown in the projections for the sub catchment [23] on Figure 2.

Since water is not traded in markets, prices do not adjust automatically to reflect periods of scarcity as they do for other goods and services. Water supply and water pricing is controlled by GWASCO. Figure 3 indicates that water demand is higher than the water supplied in the sub catchment. Given the public benefits provided by many aspects of water supply and management, it could be good from an economic perspective, if the price-setting institutions could measure the true economic value of water and to use this information to establish economically rational water tariffs. Inefficient prices of water allocation would alter land-use patterns, industrial location decisions, and other important factors. The sum of all these individual decisions determines the sustainability of 


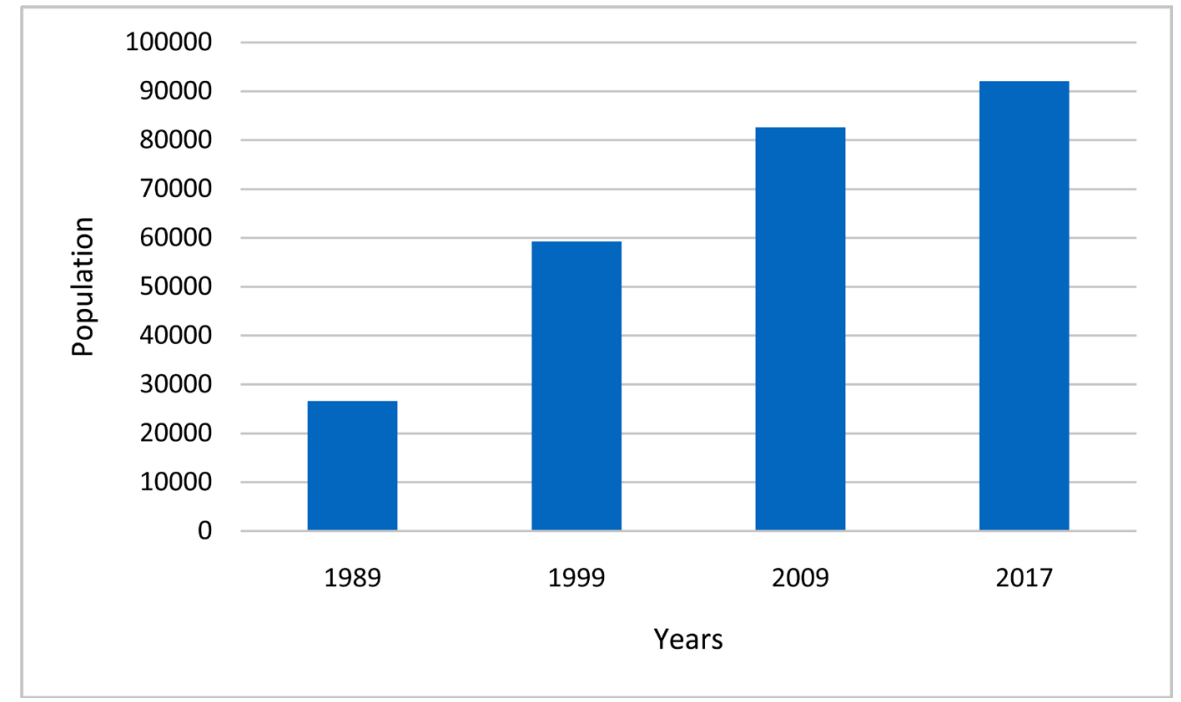

Figure 2. Population in Nyakomisaro sub catchment [23].

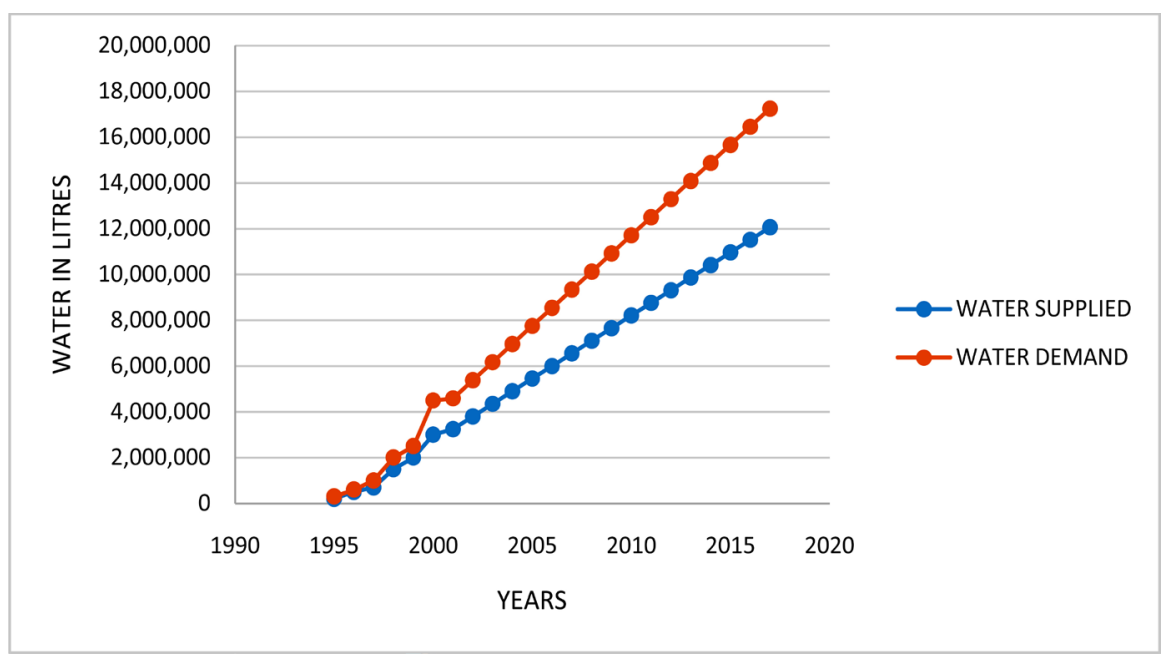

Figure 3. Water demand and water supplied in Nyakomisaro sub catchment.

local and regional water resources.

Population growth poses water supply stresses resulting in the need to develop new water sources as the water demand is higher than the water supply with the demand-supply gap increasing with time into the future. The water is priced and regulated by GWASCO, but the water's true economic value is not often reflected in the water tariffs provided. Inefficient prices of water allocation affect the level of industrial, agricultural and commercial development of an area. Efficient water pricing, key in all sectors could best be calculated on monthly basis.

For the individual households, it was observed that about 23\% travel between 100 to $200 \mathrm{~m}$ while $34 \%$ travel more than $200 \mathrm{~m}$ to fetch water. The study shows that $42 \%$ of the households use more than 7 buckets of water per day for their domestic needs usually based on household size, the majority (66\%) of which falls between 3 and 6 . About $65 \%$ of the respondents have resorted to use stream water directly from the river. Since $52 \%$ of the population has lived in the sub 
catchment for more than seven years and 57\% of the population lack piped water, pressure on the available water resources on the unprotected streams in the rural areas is high. Rainwater harvesting has to be explored as potential source of reliable water supply in the rural areas, but this also requires adequately designed systems, in terms of storage capacity and catchment area. Apart from domestic uses, water in the stream is also used to wash vehicles, watering trees in the nurseries and by water vendors.

Some households and GWASCO indicated that the challenges of water supply in the study area are related to rapid growth of Kisii Municipality as a result of many upcoming commercial activities. GWASCO needs to upgrade the old waters supply system and would need the cooperation of the land owners. The GWASCO Company should be given financial support to ensure proper upgrading of her services and adequate monitoring of illegal connections in addition to making necessary repairs.

\subsection{Storm Water Management}

The study reveals that there are no proper drainage systems or storm management plans available in Nyakomisaro sub catchment. No cleaning or removal of stumps and solid wastes has been effected in the river as evidenced by the collapse or overflow of $70 \%$ of bridges for a period exceeding one week (Figure 4). Bridges such as Daraja Moja and Nyambera have collapsed at least three times during high rains during which time vehicles using alternative roads pose danger. The bridge near Kisii prisons usually overflows during heavy rains sweeping away livestock and in some cases the young and old who are vulnerable.

Contrastingly, the river was almost dry during May in the same year as indicated in Figure 5.

Anthropogenic and climatic factors in the sub basin drive the hydrologic behavior of the sub basin as depicted by the monthly flows for the Nyakomisaro River at IKA5 (Figure 6).

The rate at which houses are constructed in Kisii town is high although some of these houses are not approved as those built adjacent to the river banks posing unfavorable ecological consequences (Figure 7).

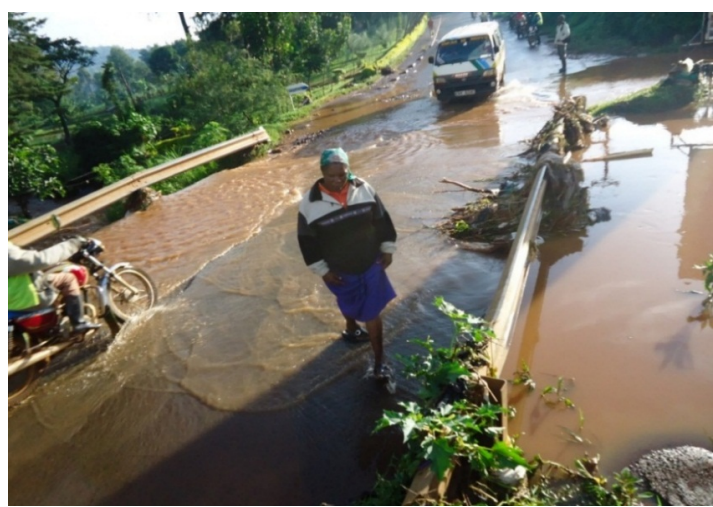

Figure 4. The River overflowing during a rainfall storm on $13^{\text {th }}$ December 2013. 


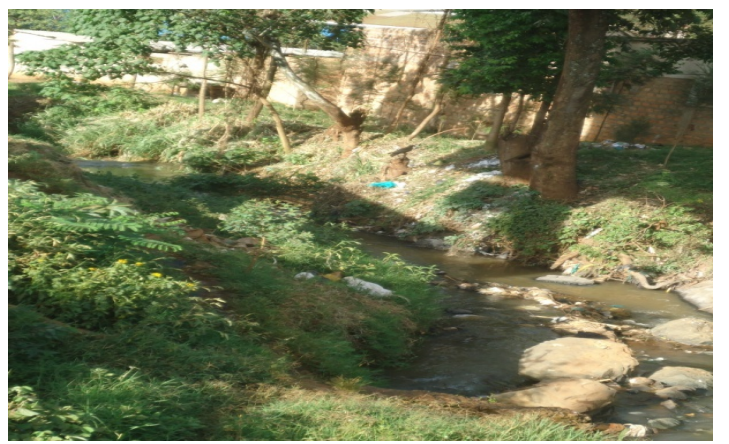

Figure 5. River Nyakomisaro's diminished water level during May 2013.

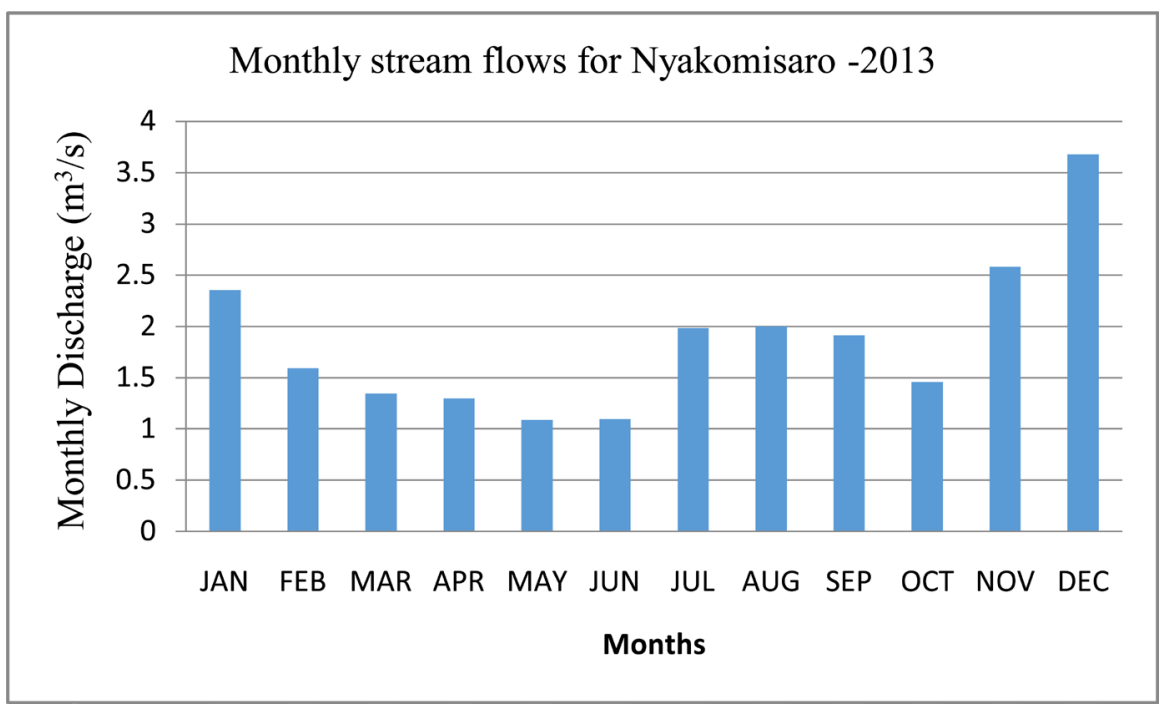

Figure 6. River Nyakomisaro mean monthly discharge during 2013.

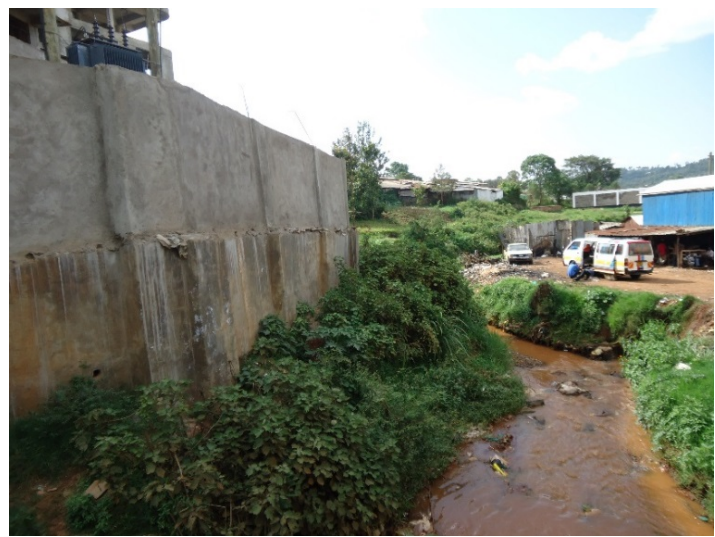

Figure 7. Construction of house adjacent to River Nyakomisaro (Photo: B. Mokaya: 2/10/2013).

The uncontrolled constructions also diminish the quality of the water upon which the urban poor depend. Further, drainage problems lead to consequential flooding and increase in siltation and sedimentation.

The Nyakomisaro sub catchment residents have not been sensitized on matters to do with storm water management and soil conservation. There are nei- 


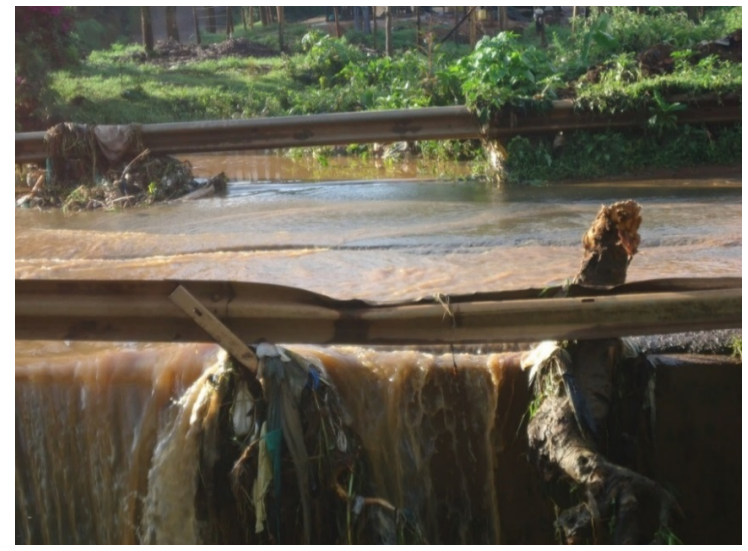

Figure 8. River Nyakomisaro carrying solid wastes on $25^{\text {th }}$ September 2013.

ther storm water management structures nor any plans existing in the municipality to check pollution challenges. Storm water control at construction sites is neglected. Usually, hydrologic alteration becomes noticeable when the imperviousness hits $10 \%$ in the drainage area. In the entire sub catchment, the level of imperviousness is on the increase given the construction of buildings and road development raising the level of urbanization with its potential for solid waste threats as indicated on Figure 8.

Alternative ways of managing the watershed should be effected by WRMA. These should match with the rate of population growth, emerging commercial activities and industrial patterns in the watershed.

\section{Recommendations}

Methods of rainwater harvesting would help reduce overreliance on river water. Since changes in water availability have the potential to impact such activities as agriculture and water supply, the effects of rainfall variation need to be incorporated in planning and policy formulation in the sub catchment.

GWASCO needs efficiency in effective monitoring to minimize wastage and leakages in the dilapidated systems. Allocation of adequate funds for watershed management could ensure sustainable water supply against impacts of population pressure and environmental degradation. The role of IWRM in sustainable water supply and delivery of services in Kisii municipality is in the assurance of a healthy non-dying Nyakomisaro River.

Kisii municipality should make deliberate attempts to clean up River Nyakomisaro to enhance free movement of water in the stream to reduce unwarranted human and animal danger as well as destruction of property. Hydraulic structures such as bridges should be built and maintained considering the river discharges during high storms and these should be in tandem with the levels of development within the sub catchment. This could be achieved through involvement of WRUA's and WRMA. There should be protection of the riverine environment against any encroachment and here NEMA should be in the fore. Chances of houses collapsing and waste materials in the river should be mini- 
mized with efforts made to involve the community in water management. Promotion of green technology in storm water management in the sub catchment involving planting grasses to reduce speed and volume of urban runoff are recommended. Buffer strips of trees, shrubs, and grasses parallel to the stream, storm water ponds for solids to settle during and between storms will be desirable.

Storm water has diverse effects to the riverine environment such as collecting and depositing pollutants of various types such as biological, chemical and physical contaminants. These pollutants have devastating effects to aquatic life in addition to enhancing to erosion processes. Safe drinking water to low class urbanites should be ensured by managing municipal waste coming from distinct point sources usually worsened by large quantities of storm water coming in from an ever growing urban landscape during higher more frequent storms that may occur from the climate change impacts. How to really address the problem of storm water from point sources which mixes up and spreads over the entire landscape is yet not clear.

GWASCO, WRMA and other stakeholders including researchers have a role in the realization of sustainable water resources utilization in the sub catchment. Regulations to reduce settlement along the river, curbing non-point and point sources of pollution and encouraging greater infiltration of water in the sub catchment would be critical.

\section{Conclusions}

Water from rain in the sub catchment in form of storm runoff is a menace. It carries sewage and pollutants from nonpoint and point sources thereby jeopardizing the water quality. Storm water can damage bridges and accelerate soil erosion. This generally affects the welfare and health of human life. Controlled storm water could translate to improved water supply, good health, economic prosperity, enhanced public safety, ecosystem stability and reduction in flood related risks such as collapsing of buildings and bridges.

Considering the storm water impact, strategies need to be developed by all stakeholders including Water User's Association (WUA), GWASCO, line ministries and WRMA. Some of the interventions suggested include: development of non-impervious road networks, planting of vegetation to help reduce surface runoff, controlling the number of constructions and riparian activities along river Nyakomisaro. Kisii municipality should develop a storm water management plan that should focus on ways of harvesting storm water for future use, regulations on pervious surfaces, introduction of bio-filtration and; creating awareness about impacts of storm water and how to control it. The information about drainage would be useful in preventing floods and hence point sources of pollution from construction sites will be minimized. Sustainable water supply for the Kisii municipality and environs can be achieved by adhering to best management practices (BMPs) and integrity of the eco hydrology of the Nyakomisa- 
ro sub catchment.

The rainfall variation critically influences water allocation decisions by GWASCO and analysis of rainfall would enhance the management of water resources and its effective utilization in Nyakomisaro sub catchment where population and economic growth have put pressure on available water resources. The number of households is depending on piped water alarmingly low. Water needs should be well catered for in the sub catchment so as to ensure the realization of sustainable agriculture, industrialisation and ecosystem health.

\section{Acknowledgements}

The authors wish to thank all the stakeholders, especially the Kenya Meteorological Department (KMD), the Water Resources Management Authority (WRMA) Kisii and GWASCO for data and insights. We are grateful to our respondents and the anonymous reviewer. This work was part of the Msc. study in Hydrology and Water Resources undertaken by the second author at Kenyatta University, Kenya.

\section{References}

[1] Njuguna, S. (2006) Hydrological Impacts of Land Use Changes on Water Resources Management and Socio-Economic Development of Upper Ewaso Ng'iro River Basin in Kenya. University of Nairobi, Kenya.

[2] Wonder, H. (2007) Assessing the Challenges of Water Supply in Urban Ghana: The Case of North Teshie, Stockholm.

[3] Lagerblad, L. (2010) Assessment of Environmental Flow Requirements in Buzi River Basin. Uppsala University, Mozambique.

[4] Howard, G. (2003) Domestic Water Quantity, Service Level and Health. WHO, Geneva.

[5] Owuor, S. (2009) Water Reforms and Interventions in Urban Kenya, Institutional Set-Up, Emerging Impact and Challenges. University of Nairobi, Kenya.

[6] WHO (1997) Guidelines for Drinking-Water Quality, Volume 3: Surveillance and Control of Community Water Supplies. 2nd Edition, WHO, Geneva.

[7] Olmstead, S. and Stavins, R. (2007) Managing Water Demand. Price verses Non-Price and Conservation Programs. Pioneer Institute, Yale University Press.

[8] Nyirabu, C. (2003) Implementation, Coordination and Management of Lake Victoria Environmental Management Project (LVEMP). Mwanza, Tanzania.

[9] Mokaya, B. (2015) The Effects of Hydrological Characteristics of River Nyakomisaro on the Water Supply of Kisii Municipality. Unpublished Msc. Thesis, Kenyatta University, $116 \mathrm{p}$.

[10] Vigneswaran, S. (2006) Quantity and Quality of Drinking Water Supplies. University of Technology, Sydney.

[11] Mati, B., Mutie, S., Home, P. and Mtalo, F. (2008) Impacts of Land-Use/Cover Changes on the Hydrology of the Transboundary Mara River, Kenya/Tanzania. Lakes \& Reservoirs. Research \& Management, 13, 169-177. https://doi.org/10.1111/j.1440-1770.2008.00367.x

[12] Olang, L. and Kundu, P. (2011) Land Degradation of the Mau Forest Complex in 
Eastern Africa: A Review for Management and Restoration Planning. In: Ekundayo, E., Ed., Environmental Monitoring, InTech, Rijeka, 245-262.

[13] Shook, A. (2009) A Study of 24-Hour High Flow Events in Small Scale New York State Watersheds. Cornell University, New York.

[14] UN-Habitat (2007) Situational Analysis and Training Needs Assessment Report. Nwsc External Services Unit, Kampala.

[15] Mokaya, B. (2014) The Hydrological Variability and Its Influence on the Water Availability, Demand and Allocation in Nyakomisaro Watershed, Kisii County. Hydrological Society of Kenya, 231-240.

[16] Ongwenyi, S., Kitheka, J. and Nyagaga, J. (1993) Impact of Hydrological and Land Use Processes on the Quality of Water in Gucha Catchment, South West Kenya. University of Nairobi, Kenya.

[17] Obiero, K. (2009) Water Resource Challenges and Their Management in River Gucha-Migori Sub-Basin, Western Kenya. Unpublished Ph.D. Thesis, Kenyatta University, Nairobi.

[18] WMO (2008) Guide to Hydrological Practices Volume I Hydrology-From Measurement to Hydrological Information WMO-No. 168.

[19] Saeid, O., Saeid, E. and Jan, A. (2015) Water Reuse in Rainwater Harvesting: Urban Water Reuse Handbook. CRC Press, Boca Raton, Florida.

[20] Van de Vyver, H. (2012) Spatial Regression Models for Extreme Precipitation in Belgium. Water Resources Research, 48. https://doi.org/10.1029/2011WR011707

[21] Mutie, M., Mate, B., Home, P., Gawain, H. and Gathenya, J. (2006) Evaluating Land Use Change Effects on River Flow Using USGS Geospatial Stream Flow Model on Mara River Basin, Kenya. Center for Remote Sensing of Land Surfaces, Bonn.

[22] Mutua, B. and Klik, A. (2007) Predicting Daily Streamflow in Ungauged Rural Catchments: The Case of Masinga Catchment, Kenya. Hydrological Sciences Journal, 52, 292-304. https://doi.org/10.1623/hysj.52.2.292

[23] GOK (2010) The 2009 Population and Housing Census. Kenya National Bureau of Statistics (KNBS), Government Printer, Nairobi.

[24] Vinay, V. (2003) Remote Forcing of East African Rainfall and Relationships with Fluctuations in Levels of Lake Victoria. International Journal of Climatology, 23, 67-89. https://doi.org/10.1002/joc.861

[25] David, M. and George, M. (2005) Introduction to the Practice of Statistics. 5th Edition, W.H. Freeman \& Company, London.

[26] CEDARE (2014) Nile River Basin M\&E Rapid Assessment Report. Monitoring \& Evaluation for Water in North Africa (MEWINA) Project, Water Resources Management Program, CEDARE. 
Submit or recommend next manuscript to OALib Journal and we will provide best service for you:

- Publication frequency: Monthly

- 9 subject areas of science, technology and medicine

- Fair and rigorous peer-review system

- Fast publication process

- Article promotion in various social networking sites (LinkedIn, Facebook, Twitter, etc.)

- Maximum dissemination of your research work

Submit Your Paper Online: Click Here to Submit

Or Contact service@oalib.com 